\title{
11
}

\section{SEPARATE WORLDS? \\ EXPLAINING THE CURRENT \\ WAVE OF REGIONAL \\ ECONOMIC POLARIZATION ${ }^{1}$}

\author{
Michael Storper
}

Regional inequality is proving too politically dangerous to ignore.

(The Economist 2016)

\section{The challenge}

Over the past 40 years, globalization has spread development to many parts of the world. But within countries, development has become more uneven, a phenomenon known as interregional divergence or polarization. This phenomenon poses a major challenge to theories used in economic geography and regional economics. In this chapter, I discuss some of these challenges and argue for a broader and more enriched framework moving forward. I refer mostly to the US-American case, but the phenomenon is widespread throughout the world, and the lessons for theory and evidence are similar for these other cases.

The variance of per capita personal income among US metropolitan areas was 30\% higher in 2016 than it was in 1980 (Ganong and Shoag 2017). In the European Union, inequality among NUTS-2 regions, after falling in the 1990s from a high level in 1980 (prior to intensified European integration), has turned sharply up again in the new millennium. In the United States, interregional migration has dropped to half of its century-long average up to 1980, and it is more spatially selective by skill level (Kaplan and Schulhofer-Wohl 2012; Giannone 2017). At the same time, labor force participation rates have a higher interregional variance in the EU and the US than since the Great Depression of the 1930s. Intergenerational mobility increasingly differs by region (Chetty et al. 2014). The divergent new geography of employment and incomes thus seems to correspond to a divergent new geography of opportunities. 
This polarization contrasts with the broad geographical development patterns from the middle of the 20th century. From 1940 to about 1980, variation in interstate incomes in the United States steadily narrowed, and suburbs and metropolitan hinterlands grew more in terms of population and incomes than innermetropolitan areas. It is for this reason that we refer today to the geography of the last few decades as a 'great inversion.'

The geographical polarization of opportunity seems to be mirrored in geographical splits in political attitudes and voting behavior (Spicer 2018). In the 2016 Brexit referendum and US and French (first round) presidential elections, there were sharp divisions between urban and less urban, prosperous regions and less prosperous ones, regions with higher average levels of education and those with lower levels, and regions with less ethnic diversity and those with more. The basic density gradient of employment, income, and opportunity creates sharp cleavages in perceptions and politics. Thus, to take the US example, Hillary Clinton prevailed in just 473 of the 3144 US counties, but with supermajorities in the most densely populated areas. Trump prevailed, but with generally narrower majorities, in the vast majority of counties that were on average much less densely populated. Generally speaking, there is long-term geographical polarization of the US House of Representatives (Bishop and Cushing 2008; Sussell and Thomson 2015). It seems as if, increasingly, people from different regions within the same country are living in subjectively separate worlds.

We should be concerned about these forms of polarization for both economic and political reasons. As the Economist (2016) points out, 'orthodox economics has few answers to the problem of regional inequality, and I will argue that the same could be said for the allied field of economic geography. Regional economics and economic geography together face the challenge of developing analytics that can explain these outcomes and designing better policies so as to spread prosperity because, as the same Economist article states, 'if economists cannot provide answers, populist insurgents will' (The Economist 2016).

\section{Spatial equilibrium theories: revisiting the roles of amenities, housing, and jobs}

In the past 20 years, the field of RSUE has developed a set of general equilibrium models that place factor mobility (and hence, the sorting of factors among regions) at the center of its narrative.

In the strongest standard version, households choose regions by arbitraging a wide variety of preferences, with the key ones consisting of nominal income, housing type and cost, and a variety of priced and unpriced amenities, while avoiding disamenities (Glaeser 2008). The model generates a powerful narrative about US regional development over the past 50 years. During a first wave of migration beginning as far back as the 1960s, people picked up and moved from the Northeast and Midwest Rust Belts of the USA to the Sunbelt in search of warmer winters and cheaper housing. They accepted generally lower nominal wages than in their 
regions of origin, but their resulting real incomes were at least equal due to access to cheaper housing, or - in an alternative version - their total utility increased due to better and more housing and amenities, such as warmer winters or lower density living and more recreation.

Spatial equilibrium researchers later turned to the selective resurgence of certain cities such as New York and Boston in the Rust Belt, as well as the strong growth of high-cost cities such as San Francisco or Seattle. These accounts center around a switch in preferences on the part of higher-skilled workers to interact in close proximity with other skilled people (Glaeser and Mare 2001). These skilled people, represented by the creative class, also wanted access to newly resurgent urban amenities, such as gyms, restaurants, parks, and hip entertainment and urban buzz in general. Notice that spatial equilibrium theory is methodologically very individualist: it focuses on choices made by individuals and households in light of their preferences. While there are some exceptions, most spatial equilibrium papers do not mention structural forces such as the shift in the location of jobs and industries or changes in income distribution, that is to say, the economic and geographical restructuring of work.

A second feature to underscore is that the key point of all the work involving spatial equilibrium is the idea of tradeoffs or arbitraging. More importantly, in order to understand the economics, this encompasses the idea that some places might have high nominal incomes and others lower nominal incomes, but that the real divergence between them is much lower, because the former are likely to have high costs of living or undesirable quality of life characteristics, while the latter will have a low cost of living. This is the difference, in these theories, between 'real income' and 'real total utility' and money income.

However, since the early 2000s, there is increasing evidence of growing divergence in not only nominal (money) wages between regions but also real terms (i.e., after adjusting for the cost of living, see Figure 11.1). Real wage convergence in the United States, a slow trend from 1880 onward, basically came to a halt sometime during the 1980s (Moretti 2012; Diamond 2016; Giannone 2017). Autor (2019), moreover, demonstrates that for college-educated workers, there were only very small gaps in wages between the regions of the US prior to 1980, on the order of $5 \%$ from the lowest to highest-wage region; but these gaps have now widened to roughly 30\%. Meanwhile, for workers with less than a college education, the gaps have narrowed. Given differences in cost of living, a less-educated worker faces a much larger penalty for living in an expensive region than before, whereas an educated worker enjoys a much greater wage benefit.

Even this is likely to underestimate the total divergence, because high-income people increasingly get access to non-priced amenities such as urban buzz simply by virtue of living where they do (Diamond 2016). The converse of this is that lower-wage workers are moving to regions where their total utility or satisfaction is now lower, and increasingly different from, the average high-wage worker in a region with a high cost of living.

The stakes in these academic exercises have now become political. This objective situation may have finally become a subjective and politicized one. The Brexit and 


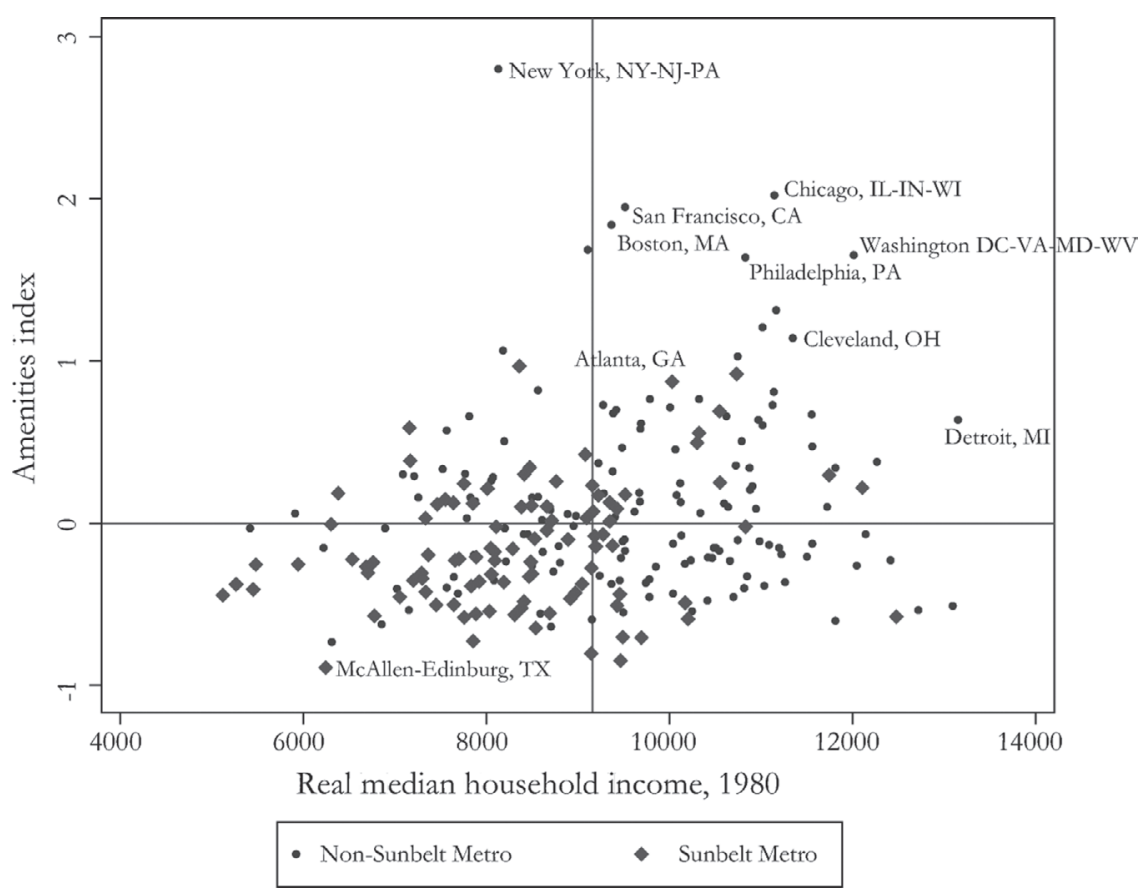

FIGURE 11.1 Amenities and real income in US metropolitan areas.

Source: Kemeny and Storper (2012).

Trump elections, as well as survey data, can be interpreted as indicating that in some regions, many people perceive their total utility to be unsatisfactory, whether or not their locations represent some type of interregional equilibrium in the distribution of people. This notion of a high level of dissatisfaction is supported by the growing literature describing how people in less prosperous regions perceive prosperous urban regions such as New York, London, Houston, Boston, and San Francisco to be better off than where they live, with the others enjoying rigged benefits, a phenomenon labeled 'the politics of resentment' (Graeber 2009; Cramer 2016; Guilluy 2016; Hochschild 2016; Isenberg 2016; Vance 2016; Gest 2016). I will return to this subjective dimension later in this chapter, when discussing values and narratives.

\section{Slower and more selective labor mobility: is it housing and amenities?}

The changing geography of wages and employment presents another challenge to urban and regional economics. If the good jobs and wages are piling up in some places rather than others, theory suggests that people will move from the low- to the high-opportunity regions. Yet, since the 1980s, there has been a significant slowdown in interstate mobility in the United States. This is coupled to 
more geographically selective mobility, where skilled persons migrate among highincome places and the less skilled stay in low-income places more than they have historically. The slowdown applies to virtually all age and skill categories (Kaplan and Schulhofer-Wohl 2012; Molloy, Smith, and Wozniak 2014).

Why would people not move? The mainstream literature on spatial economics turns to housing markets as the main source of the slowdown. The general backdrop for the slowdown in migration is that interregional housing price gaps have grown considerably since the 1990s. In the 1970s and 1980s, there was low demand for housing in the Northeast coastal cities, and an expansionist housing policy in the South and interior West. Since then, the major metropolitan regions in the Northeast and Pacific Coast have had big housing price increases compared to the rest of the country (Glaeser, Gyourko, and Saks 2005). This is a phenomenon found in major metropolitan areas around the world.

Mainstream urban economists mostly attribute high housing prices to over-regulation, and they tend to blame neighborhood groups who defend their privileges through zoning. They line up, in a rather odd coalition, with many self-styled progressive urban planners, who wish to promote dense transit-served neighborhoods and see homeowners as blocking agents. Their claims are sweeping. In a widely cited analysis, Hsieh and Moretti (2019) assert that if city-regions such as San Francisco, NYC, Washington, London, or Paris would open the floodgates for housing construction, then there would be a considerable increase in migration from the regions characterized by high unemployment and relatively low wages, such as the Upper Midwest of the USA, and the prosperous regions would grow through in-migration, but workers would enjoy higher real wages due to lower housing prices. Interestingly, a traditionally local debate about housing provision has, through the use of spatial equilibrium theory, been elevated to one of national importance and tied into debates about left-behind regions as well as spatial and social inequalities at large.

However, this expanded school of thought on deregulating housing construction has very weak empirical evidence. The idea that deregulating housing would substantially reshape a system of cities and solve the problems of inequality through migration and cheaper housing is not well sustained (Rodríguez-Pose and Storper 2020). A more likely explanation is the changing geography of employment and the growing inequality of wage income. Over the last few decades, there has been a great inversion in the geography of employment that continues today, such that metropolitan areas with more than 1 million people account for three-quarters of the net employment increase in the USA from 2010 to 2016. Population increases seem to match more consistently the places with growing employmentwhether in expensive, dense, highly regulated metropolitan areas or in cheaper, less-regulated areas. In contrast, population does not expand in cities in either of these categories where there is little employment growth: thus, there are expensive, dense old metros with little job growth (e.g., Chicago, Philadelphia), just as there are many cheap housing cities with little job growth (in the interior West and old Rust Belt). It is very unlikely, under any housing scenario, that an unskilled worker in a left-behind region would move to an expensive region such as New York, not 
for lack of housing, but rather because the employment opportunities that have grown in New York are in jobs that require high levels of education and skill. In the mid-20th century, if one were a college-educated worker, location had very little impact on one's wage. Today, on average, wages for college-educated workers in America vary by about one-third between prosperous superstar cities and other regions. Meanwhile, the geography of wages for less-skilled workers has flattened. With differences in cost of living between regions, a less-skilled worker is penalized more than in the past for living in a prosperous, high-cost region. It does not make sense for the unskilled to migrate, but it does for the skilled (Autor 2019).

In other words, a structural explanation that relies on major shifts in the geography of wages and opportunity is more effective at explaining why some people move and others do not, and hence on the fundamental roots of interregional economic divergence.

\section{Reformulation around a developmental perspective: the great inversion and the new geography of jobs, incomes, and opportunity}

How can we improve our framework to better account for the divergent development patterns of the past 30 years? Kemeny and Storper (2020) propose that there are four key elements that can shape a theory and research framework in terms of both regional economics and economic geography.

1 Macro-historical perspective: waves of technological change are endogenous to the capitalist market system and regularly disrupt convergence and even reverse it. There are successive industrial revolutions that create key new, innovative production sectors with strong agglomeration economies, as emphasized by Schumpeterian economic geographers.

2 The geography of skilled labor in each industrial revolution: the geographical centers of each industrial revolution enhance divergence by maintaining their attractiveness to skilled workers.

3 Maturity and diffusion of cutting-edge industries: at certain moments in time, convergence forces can increase, through declining innovation-generated agglomeration economies as they become more routinized and the skills required to operate them decline.

4 The changing landscape of amenities and housing: amenities and housing are weaker long-term forces than the geography of nominal wages and employment in determining whether convergence or divergence dominates. As the forces of agglomeration expand, the concentration of incomes and amenities are generated endogenously in high-income places. As the forces of agglomeration weaken, the roles of housing and exogenously supplied amenities grow stronger in determining locational choices of firms and households, while the fundamental attractiveness of agglomerations weakens, thus enhancing convergence processes. 
The current regional disparities were set in motion by a major wave of technological innovation that began in the 1970s - stimulating output in high technology, finance, and advanced service sectors that depend on agglomeration economies and therefore whose core, nonroutine jobs favor large metropolitan areas and draw from pools of skilled workers in high-turnover labor markets. This wave of technological change also allowed the routinization of previously dominant manufacturing sectors, thus decreasing their employment through automation, and revolutionized trade costs, allowing these forces to become more geographically dispersed (Levy and Murnane 2004). These epochal technological changes have been coupled with an expansion of world trade, itself an outcome of the ways in which such technologies have reduced trade and interaction costs and allowed global value chains to emerge due to routinization of tasks. This has hurt weaker regions and magnified the forces of divergence.

We need a framework to accommodate both times when migration contributes to divergence and when it reverses that role and contributes to convergence. In the mid-20th century United States, people left the deindustrializing regions of the Rust Belt to move to more dynamic ones, either on the coasts or in the South. This served as a safety valve and opportunity-increasing mechanism for migrants. In contrast, today we require a deeper understanding of why certain categories of workers continue to crowd into expensive metropolitan areas as well as the apparent slowdown in mobility of the less-skilled from lower-wage or loweropportunity regions to the prosperous metropolitan areas. We can speak of groups of the workforce who are stuck in place today; it is not a matter of their underlying desires or preferences, but rather the structural labor market forces that block their path, in both the places where they are or the more prosperous places that they might dream of reaching.

\section{The institutionalization of separate worlds}

Rodríguez-Pose (2013) argues that there is a widespread consensus that 'institutions are important to development' (Acemoglu, Johnson, and Robinson 2004; Rodrik et al. 2004; Farole et al. 2010; Acemoglu and Robinson 2012). Conventionally, a broad definition of institutions includes those that are both formal and informal. Formal institutions that shape development can range from very big framework conditions, such as constitutions, laws, and governmental structures, to very specific formal rules and laws, along with organizations that apply, enforce, and interpret them. Institutions also refers to routines, in the form of manifold informal practices, norms, conventions, and beliefs, as well as informal networks of persons and organizations (North 1990; Storper and Salais 1997). Moreover, it is widely agreed that formal institutions and informal institutions (often labeled 'culture') have two-way joint effects (Alesina and Guiliano 2015).

In what follows, I discuss four possible ways that institutions are shaping current interregional economic polarization: institutions that capture and prolong agglomeration; institutionalized value systems and interactions that influence migration, 
skills, and sorting; set institutional structures that shape skilling and socialization; and feedback to politicians, which in turn affects divergence through policy choices.

\section{Institutions, agglomeration, and divergence}

Capturing promising new industries involves the nurturing of the entrepreneurs who come up with breakthrough innovations or products and transforming older ones involves spin-off firms who aid the major existing firms to remain dynamic (Saxenian 1994; Klepper 2009; Chatterji, Glaeser, and Kerr 2013). Kenney and Mowery (2014) emphasize the different ways that business and research institutions network in regions, as the relational infrastructures that shape innovation and entrepreneurship, so that $\mathrm{R} \& \mathrm{D}$ is translated into development in different manners from one place to another. Feldman and Lowe (2017) use the case of North Carolina to make a wider argument about the gradual enhancement of regional capabilities. But the field still lacks systematic, large-scale evidence, as well as structured theories, on the preconditions that enable certain regions to capture major waves of development and others to be excluded.

A related topic is why, in this wave, agglomeration-driven advantages have concentrated in certain places, and why overall divergence has thus far been so strong relative to convergence and spreading processes. Detailed studies on existing prosperous places suggest that this might be because of the endogenous coevolution of agglomeration and the local informal institutions that are specific to certain industries and places, such as Silicon Valley and London today or Detroit and Manchester in the past.

In one prominent study, Feldman and Zoller (2012) identify new types of economic intermediary agents, such as venture capitalists and deal brokers, showing that their uneven geography accompanies the growth of knowledge-intensive industries. Other recent research along these lines has quantified the value of certain kinds of local economic networks that underpin agglomeration (Kemeny et al. 2016). Another key question for such institutional approaches is how entrepreneurs emerge, what kinds of entrepreneurs emerge, where they emerge, and whether they flourish or are inhibited by the regional economic environment (Kirzner 1979; Braunerhjelm et al. 2010; Chatterji, Glaeser, and Kerr 2013; Fairlie 2013). Taking into account all these institutional forces-existing firms, innovation, networks and leadership, conventions and world views, entrepreneurship-economic sociologists speak of the emergence of 'organizational fields' or ecologies (Powell, Packalen, and Whittington 2012; Padgett and Powell 2012), referring to a complex institutionalization process. In the language of regional economics, the places that develop the institutions mentioned earlier, in tandem with the location of firms that have cutting-edge technology or knowledge endowments, develop double monopolistic advantages, from hard economies of scale to informal institutions that are difficult to imitate or transfer. This difficulty of imitation may not last forever, but it seems to prolong the advantage and hence interregional polarization in ways not fully incorporated into either RSUE superstar city approaches or NEG agglomeration modeling. 


\section{Network-embedded skills, job search, and spatial traps}

Many scholars now consider that new economy skills are not just individual human capital but also are acquired and exercised through networks, which are in turn social institutions (Granovetter 2005; Owen-Smith and Powell 2012; Deming 2015; DeLong 2016; Kemeny et al. 2016). In this view, more formal skills are indeed required than ever before, but in addition to diplomas, there are also more experience skills that can only be acquired by 'being there' (De la Roca and Puga 2017). Experience itself appears to have several different components and geographies. One is simply having learned the unwritten or informal aspects of job performance. Another is that the high turnover and highly individualized work in the skilled sectors of the new economy require social networks: knowing people. The implication of this reasoning is that even those individuals who succeed at formal schooling in left-behind regions are increasingly disadvantaged by their location. They are less apt to acquire the informal experience, knowledge, and cues, and to build the networks that create advantages for individuals in the wealthier regions with similar levels of formal education. Such opportunities are scarcer and less 'in the air' in the less-developed regions than in those that are already ahead. If this is the case, then the institutions in the wealthier regions can also provide their students with better overall capacities by means of better networking and social cueing than in less-advantaged regions. Such differences then cumulate over the development cycle through the differential ability of families in the right regions to have the income and connections to afford their children such capacities. This could help us explain the observed increase in regional differences in return to education, especially among highly skilled workers, and the relative lack of migration from left-behind to superstar regions.

Research on skills, mobility, and interregional divergence should therefore consider education and experience in relation to strong and weak ties and how they affect sorting between regions and behaviors within them. It seems likely that this contributes to why less-skilled people find themselves more spatially trapped today than in previous waves of economic change.

\section{Organizations, values, and culture: socialization and economic divergence}

As noted earlier, institutions are generally broken down into formal and informal components, with the latter consisting of a variety of elements including values, norms, conventions, beliefs, and customs. Some theorists argue that all these informal dimensions should be described by the term 'culture' (Alesina and Guiliano 2015). There is increasing recognition that these forces can contribute to economic divergence.

Scholars such as Graeber (2009), Cramer (2016), Vance (2016), Hochschild (2016), and Williams (2017) call attention to different systems of values in different regions of the US. They argue that we should consider variables that capture 
individual characteristics in context, because it is experiences that count for people (and not just inputs such as education or outputs such as income). Operationally, two such experience-capturing variables are occupation and location. There seems to be a value split between people in manual-occupational cultures and cognitiveoccupational cultures that is sharper than the splits between people at different educational and income levels (Williams 2017). Income is less closely related to many attitudes than notions of dignity and expectations of social mobility or hope about the future (see also Inglehart and Norris 2016).

These interpretations are supported by quantitative findings on voting patterns. Gelman (2008) demonstrates that the standard individual attributes adduced to explain voting-income, religious observance, race, and ethnicity-change in importance and sometimes in direction when geographically disaggregated. For example, high-income people in US blue states vote much farther to the left than their high-income counterparts in red states, and the effect of a similar degree of religious conviction varies greatly across different places. Blue counties in the USA aggregate left-wing preferences from the two ends of the income distribution spectrum, but the upper end votes overwhelmingly right-wing in less urban places. This implies that interactions within places, and not just individual characteristics (even in combination at the individual level), determine, at least to some extent, attitude formation and voting (Gordon 2018).

All of these scholars argue that individual attributes are shaped by, and mutually causal with, the collective attributes of the places in which people live and the process by which narratives are constructed based on observation and experience. The institutions of a place are in part the organizations with which people interact and that help to define and mobilize their interests and interpretations of experience. Along these lines, Hochschild (2016) reports on a detailed ethnography of Louisiana, centering on the intersection of local institutions-churches, political parties, community associations, local political and social networks - in forging narratives or world views.

The institutions of socialization are constructed by human actors, and some of them can change in relatively short periods of time. In the case of the US, the key institutions of 'CIO unionism' ${ }^{2}$ and urban political machines have lost their force in the wake of deindustrialization in many areas of the Midwest (CIO unions were never strong in the South) (Davis 2017). CIO unionism was to the Northeast and Upper Midwest what conservative local institutions have been to the South: a key center of associational life and information for many people and their families, shaping their political choices. As CIO unions have withered due to deindustrialization and associated demographic change, other more politically and socially conservative local institutions have replaced them. As industrial cities in the Midwest have declined, those people who did not move out of the region have become more rural, and with this new rurality, their institutional attachments have changed, becoming more rural and more conservative in flavor (Cramer 2016).

An opposite form of institutional construction appears to have occurred in most major cities over the last 30 years. As noted earlier, these regions have seen the rise 
of a dense tissue of organizations in local civil society, associated with a high degree of social mobilization. These organizations lobby for inclusion of immigrants, for multiculturalism, for amenities such as transportation and recreation, for aiding the homeless, and for promoting urban cultural events and forums. The labor unions involved in these places are largely those of post-industrial, service-oriented workers (often non-white and female), in urban-based industries with strong immigrant constituencies. They have largely replaced industrial manufacturing unions as participants in big-city politics. Religious organizations are involved, but usually they are more concerned with justice-oriented approaches to urban problems than with religious conservatism. The civil society tissue of metropolitan areas is the source of much of the progressive politics, multiculturalism, and global outlook there, deviating substantially from the church, military, within-group, and family-dominated affinities that prevail in other areas. We could therefore say that the content of civil society organizations and networks has gone in very different directions in different regions, in a way that seems to track economic geographies and their demographic consequences. Ultimately, we need to better understand the interaction between technological change, labor market change, the geography of work and incomes, and political and institutional change.

\section{Political and policy polarization}

The fact that economic polarization gives rise to a differentiated landscape of objective interests is nothing new; this is the basis for a long line of literature on sectionalism and political choices in different regions. The current economic polarization has its version of this phenomenon. A key issue in determining the economic effects of trade is distinguishing between producer (wage, employment) impacts and consumer impacts, and determining how they interact differently across regions. These effects have been considered in the aggregate, where the evidence shows that increasing manufacturing trade has generated large net benefits from a consumer surplus (lower prices) in developed countries and net benefits in employment and wage incomes in developing countries. The greatest net consumer benefits are at lower ranges of the income distribution, because the wealthy consume more services and more locally produced goods than those with lower incomes. In geographical terms, this probably means that regions hit hardest by import competition with regard to wages and employment probably exhibit rather high consumer surpluses on the consumption side (the 'Walmart' effect). People in wealthier regions also enjoy a consumer surplus from imports, but because they consume more locally produced services, these are lower on a proportional basis. Skilled people in prosperous regions probably benefit more from the presence of low-wage immigrant labor, which provides them with labor-intensive services, more than is the case in less wealthy regions. In the latter, immigrants are likely to compete with low-skill native workers more than in metropolitan regions (Foged and Peri 2016). These structural factors will help us explain the divergent attitudes toward globalization and multiculturalism that manifest geographically today. 


\section{Rising to the challenge}

I opened this chapter by noting the double challenge identified by the Economist: orthodox economics has few answers to the problem of regional inequality, and yet, if we do not provide some answers, populist insurgents will do so. I have attempted to propose a broader framework with which we could seek these answers. This framework would apply micro-economic analyses of employment location, wages, the role of housing and amenities, skills, and migration, and place them within a broad structural and developmental framework. This is ultimately a multi-disciplinary effort. The stakes are high because geographical polarization is a threat to social and economic stability and justice in the contemporary world.

\section{Acknowledgements}

I thank Harald Bathelt, Tom Kemeny, Henry Overman and CEP London seminar participants, as well as several anonymous referees, for their detailed and insightful critiques of two previous versions. I also benefited from comments of participants at the 'Globalization in Crisis' conference at Cambridge in July 2017.

\section{Notes}

1 Shortened and partly updated reprint: Storper, Michael. 2018. "Separate Worlds? Explaining the Current Wave of Regional Economic Polarization." Journal of Economic Geography 18 (2): 247-270. doi: 10.1093/jeg/lby011.

$2 \mathrm{CIO}$ unionism as the progressive branch of AFL-CIO, consisting of a more politicized 'European style' and class-oriented union than the AFL local unions. When the two merged, AFL 'bread and butter' unionism came to dominate in the United States, but locally, many $\mathrm{CIO}$ unions were already in place and played an important role in those communities long after the merger.

\section{References}

Acemoglu, Daron, Simon Johnson, and James A. Robinson. 2004. "Institutions as the Fundamental Cause of Long-Run Growth." Working Paper 10481. Cambridge, MA: National Bureau of Economic Research.

Acemoglu, Daron, and James A. Robinson. 2012. Why Nations Fail: The Origins of Power, Prosperity, and Poverty. London: Profile Books.

Alesina, Alberto, and Paola Guiliano. 2015. "Culture and Institutions." Journal of Economic Literature 53 (4): 898-944.

Autor, David H. 2019. "Work of the Past, Work of the Future." AEA Papers and Proceedings 109: 1-32.

Bishop, Bill, and Robert G. Cushing. 2008. The Big Sort: Why the Clustering of Like-Minded Americans is Tearing Us Apart. New York: Houghton-Mifflin.

Braunerhjelm, Pontus, Zoltan J. Acs, David B. Audretsch, and Bo Carlsson. 2010. "The Missing Link: Knowledge Diffusion and Entrepreneurship in Endogenous Growth." Small Business Economics 34 (2): 105-125.

Chatterji, Aaron, Edward L. Glaeser, and William R. Kerr. 2013. "Clusters of Entrepreneurship and Innovation." Working Paper 19013. Cambridge, MA: National Bureau of Economic Research. 
Chetty, Raj, Nathaniel Hendren, Patrick Kline, and Emmanuel Saez. 2014. "Where is the Land of Opportunity? The Geography of Intergenerational Mobility in the United States" Quarterly Journal of Economics 129 (4): 1553-1623.

Cramer, Katherine J. 2016. The Politics of Resentment: Rural Consciousness in Wisconsin and the Rise of Scott Walker. Chicago: University of Chicago Press.

Davis, Mike. 2017. "The Great God Trump and the White Working Class." Jacobin, July 2.

De la Roca, Jorge, and Diego Puga. 2017. "Learning by Working in Big Cities." Review of Economic Studies 84 (1): 106-142.

DeLong, Bradford J. 2016. "Regional Policy and Distributional Policy in a World Where People Want to Ignore the Value and Contribution of Knowledge and Network-Based Returns." Accessed March 1, 2018. www.bradford-delong.com/2016/12/16/.

Deming, David J. 2015. "The Growing Importance of Social Skills in the Labor Market." Working Paper 21473. Cambridge, MA: National Bureau of Economic Research.

Diamond, Rebecca. 2016. "The Determinants and Welfare Implications of US Workers' Diverging Location Choices by Skill, 1980-2000." American Economic Review 106 (3): 479-524.

(The) Economist. 2016. "Place-Based Economic Policies as a Response to Populism.” December 15 .

Fairlie, Robert W. 2013. "Entrepreneurship, Economic Conditions, and the Great Recession." Journal of Economics and Management Strategy 22 (2): 207-231.

Farole, Thomas, Andrés Rodríguez-Pose, and Michael Storper. 2010. "Human Geography and the Institutions that Underlie Economic Growth.” Progress in Human Geography 35 (1): $58-80$.

Feldman, Maryann P., and Nichola Lowe. 2017. "The Unbearable Lightness of Effective Policy." Unpublished Paper. Chapel Hill, NC: University of North Carolina, School of Public Policy.

Feldman, Maryann P., and Ted D. Zoller. 2012. "Dealmakers in Place: Social Capital Connections in Regional Entrepreneurial Economies.” Regional Studies 46 (1): 23-37.

Foged, Mette, and Giovanni Peri. 2016. "Immigrants' Effect on Native Workers: New Analysis of Longitudinal Data." American Economic Journal: Applied Economics 8 (2): $1-34$.

Ganong, Peter, and Daniel W. Shoag. 2017. "Why Has Regional Income Convergence in the U.S. Declined?” Working Paper 23609. Cambridge, MA: National Bureau of Economic Research.

Gelman, Andrew. 2008. Red State, Blue State, Rich State, Poor State: Why Americans Vote the Way They Do. Princeton: Princeton University Press.

Gest, Justin. 2016. The New Minority: White Working Class Politics in an Age of Immigration and Inequality. Oxford: Oxford University Press.

Giannone, Elisa. 2017. "Skill-Biased Technical Change and Regional Convergence." 2017 Meeting Papers 190. Society for Economic Dynamics.

Glaeser, Edward L. 2008. Cities, Agglomeration, and Spatial Equilibrium. Oxford: Oxford University Press.

Glaeser, Edward L., Joseph Gyourko, and Raven Saks. 2005. "Why is Manhattan So Expensive? Regulation and the Rise in Housing Prices." Journal of Law and Economics 48 (2): 331-369.

Glaeser, Edward L., and David C. Maré. 2001. "Cities and Skills.” Journal of Labor Economics 19 (2): 316-342.

Gordon, Ian R. 2018. "In What Sense Left Behind by Globalization? Looking for a Less Reductionist Geography of the Populist Surge in Europe" Cambridge Journal of Regions, Economies and Societies 11 (1): 95-113. 
Graeber, David. 2009. "Value, Politics and Democracy in the United States." Current Sociology 59 (2): 186-199.

Granovetter, Mark. 2005. “The Impact of Social Structure on Economic Outcomes.” Journal of Economic Perspectives 19 (1): 33-50.

Guilluy, Christophe. 2016. La Crépuscule de la France d'en haut [The Twilight of France from Above]. Paris: Flammarion.

Hochschild, Arlie R. 2016. Strangers in Their Own Land: Anger and Mourning on the American Right. New York: The New Press.

Hsieh, Chang-Tai, and Enrico Moretti. 2019. "Housing Constraints and Spatial Misallocation." American Economic Journal: Macroeconomics 11 (2): 1-39.

Inglehart, Ronald F, and Pippa Norris. 2016. "Trump, Brexit, and the Rise of Populism: Economic Have-Nots and Cultural Backlash." HKS Faculty Research Working Paper Series RWP16-026. Cambridge, MA: Harvard Kennedy School.

Isenberg, Nancy. 2016. White Trash: The 400-Year Untold History of Class in America. New York: Viking.

Kaplan, Greg, and Sam Schulhofer-Wohl. 2012. "Understanding the Long-Run Decline in Interstate Migration." Working Paper 18507. Cambridge, MA: National Bureau of Economic Research.

Kemeny, Thomas, Maryann P. Feldman, Frank Ethridge, and Ted Zoller. 2016. "The Economic Value of Local Social Networks.” Journal of Economic Geography 16 (5): 1101-1122.

Kemeny, Thomas, and Michael Storper. 2012. "The Sources of Urban Development: Wages, Housing, and Amenity Gaps Across American Cities.” Journal of Regional Science 52 (1): 85-108.

Kemeny, Thomas, and Michael Storper. 2020. "Superstar Cities and Left-behind Places: Disruptive Innovation, Labor Demand, and Interregional Inequality." Working Paper 41. London: LSE International Inequality Institute.

Kenney, Martin, and David C. Mowery, eds. 2014. Public Universities and Regional Growth: Insights from the University of California. Stanford: Stanford University Press.

Kirzner, Israel M. 1979. Perception, Opportunity, and Profit: Studies in the Theory of Entrepreneurship. Chicago: University of Chicago Press.

Klepper, Steven. 2009. "Silicon Valley, a Chip off the Old Detroit Bloc." In Entrepreneurship, Growth, and Public Policy, edited by Zoltan J. Acs, David B. Audretsch, and Robert J. Strom, 79-116. Cambridge: Cambridge University Press.

Levy, Frank, and Richard J. Murnane. 2004. The New Division of Labor: How Computers Are Creating the Next Job Market. New York: Russell Sage Foundation.

Molloy, Raven, Christopher L. Smith, and Abigail Wozniak. 2014. "Declining Migration within the U.S.: The Role of The Labor Market." Working Paper 20065. Cambridge, MA: National Bureau of Economic Research.

Moretti, Enrico. 2012. The New Geography of Jobs. Boston: Houghton Mifflin Harcourt.

North, Douglass C. 1990. Institutions, Institutional Change and Economic Performance. Cambridge: Cambridge University Press.

Owen-Smith, Jason, and Walter W. Powell. 2012. "Networks and Institutions." In The Sage Handbook of Organizational Institutionalism, edited by Royston Greenwood, Christine Oliver, Roy Suddaby, and Kerstin Sahlin-Andersson, 594-621. Los Angeles: Sage.

Padgett, John F., and Walter W. Powell, eds. 2012. The Emergence of Organizations and Markets. Princeton: Princeton University Press.

Powell, Walter W., Kelley Packalen, and Kjersten B. Whittington. 2012. "Organizational and Institutional Genesis: The Emergence of High-Tech Clusters in the Life Sciences." In The Emergence of Organizations and Markets, edited by John F. Padgett, and Walter W. Powell, 434-465. Princeton: Princeton University Press. 
Rodríguez-Pose, Andrés. 2013. "Do Institutions Matter for Regional Development?" Regional Studies 47 (7): 1034-1047.

Rodríguez-Pose, Andrés, and Michael Storper. 2020. "Housing, Urban Growth and Inequalities: The Limits to Deregulation and Upzoning in Reducing Economic and Spatial Inequality." Urban Studies 57 (2): 223-248.

Rodrik, Dani, Arvind Subramanian, and Francesco Trebbi. 2004. "Institutions Rule: The Primacy of Institutions Over Geography and Integration in Economic Development." Journal of Economic Growth 9 (2): 131-165.

Saxenian, AnnaLee. 1994. Regional Advantage: Culture and Competition in Silicon Valley and Route 128. Cambridge, MA: Harvard University Press.

Spicer, Jason. 2018. "Electoral Systems, Regional Resentment and the Surprising Success of Anglo-American Populism." Cambridge Journal of Regions, Economy and Society 11 (1): $115-141$

Storper, Michael, and Robert Salais. 1997. Worlds of Production: The Action Frameworks of the Economy. Cambridge, MA: Harvard University Press.

Sussell, Jesse, and James A. Thomson. 2015. Are Changing Constituencies Driving Rising Polarization in the U.S. House of Representatives? Santa Monica: RAND Corporation.

Vance, J. D. 2016. Hillbilly Elegy: A Memoir of a Family and Culture in Crisis. New York: Harper.

Williams, Joan C. 2017. White Working Class: Overcoming Class Cluelessness in America. Boston: Harvard Business Review Press. 